\title{
Kompozit kolonik adenom-mikrokarsinoid tümör, gerçekten tesadüf mü? Olgu sunumu
}

\section{Compozite colonic adenoma-microcarcinoid tumor, is really a coincidence? Case report}

\author{
Mehmet ZENGIN ${ }^{1 *}$, Hüsniye Esra PAŞAOĞLU² \\ 'Yozgat Devlet Hastanesi, Patoloji Kliniği, Yozgat, \\ ${ }^{2}$ Bağcılar Eğitim ve Araştırma Hastanesi, Patoloji Kliniği, İstanbul, TÜRKIYE
}

\section{öz}

Mikst adenonöroendokrin kanserler nadir rastlanan tümörlerdir. Kolonik tübüler adenomlar ile mikrokarsinoid tümörlerin birlikteliği ise literatürde son derece ender bildirilmiștir. Bilindiği üzere, bu tümörlerdeki nöroendokrin bileşen glandüler patern, iğsi hücreli patern, skuamöz-osteoid metaplazi veya pleomorfizm gibi belirgin hitopatolojik değişkenlik gösteren geniş bir yelpaze sergiler. Nadiren çok az farklılaşmış olabilir ve undiferansiye karsinom ya da lenfomaya benzeyebilirler. Bununla beraber, karsinoid veya Zollinger-Ellison gibi birtakım sendromlarla ilişkili karsinoid tümörlerin immünohistokimyasal analizinde, bir amin veya peptit baskın olabileceği gibi çoğunun mültihormonal olduğu gösterilmiştir ve primer tümördeki aminler ve peptidler, üstte bulunan endokrin hücrelerde normal olarak bulunanlarla çoğu zaman eşleşmez. Ayrıca son zamanlarda, neoplastik endokrin ve endokrin dışı epitel hücrelerinin karışımlarını içeren artan sayıda tümör tarif edilmiştir. Dahası, endokrin ve epitel hücresi özelliklerinin aynı hücre içinde gözlendiği farklı tümör türleri de mevcuttur. Bütün bu literatür bilgileri ile benzer olarak, olgumuzda izlenen morfolojik ve immünhistokimyasal bulgular iki neoplastik bileşenin ortak bir öncü hücreden kaynaklandığını göstermektedir.

Anahtar kelimeler: kompozit adenom, mikrokarsinoid, tübüler

\section{ABSTRACT}

Mixed adenoneuroendocrine cancers are rare tumors. The association of colonic tubulary adenomas with microcarcinoid tumors has been reported very rarely in the literature. As known, the neuroendocrine component in these tumors display a broad spectrum with marked variability in histopathology properties; such as glandular pattern, spindle cell pattern, squamousosteoid metaplasia or pleomorphism. Rarely, they may be very poorly differentiated and may resemble undifferentiated carcinoma or lymphoma. In addition, immunohistochemical analysis of carcinoid tumors associated with some syndromes such as Zollinger-Ellison and carcinoid has shown that, most are multihormonal as well as one amine or peptide may predominate and the amines and peptides in the primary tumor do not often match to those normally found in the overlying endocrine cells. However, an increasing number of tumors have recently been described including mixtures of neoplastic endocrine and nonendocrine epithelial cells. Furthermore, there are different types of tumors in which endocrine and epithelial cell characteristics are observed in the same cell. Similar to all this literature information, morphological and immunohistochemical findings in our case show that, the two neoplastic components originate from a common precursor cell.

Key words: compozite adenoma, microcarcinoid, tubulary 


\section{Giriş}

Mikst glandüler-nöroendokrin neoplaziler, endokrin ve glandüler komponenti birlikte içeren nadir görülen bir tümör grubunu tanımlar [1]. Bu isimlendirme için her bir komponentin de, difüz ya da lokalize, tümörün en az üçte birini oluşturması gerekmektedir [1]. Dünya Sağlık Örgütü 2010 sınıflamasında, mikst adenonöroendokrin karsinom kategorisinde yer alan bu tümörlerin tanımlamasında, her iki komponent de malign olarak belirtilmiştir $[1,2]$. Tübüler adenom ve mikrokarsinoid tümör birlikteliği ise literatürde son derece nadir olarak bildirilmiş olup olguların çoğu midede lokalizedir [3,4]. Bu tanımlama hem glandüler hem de nöroendokrin komponentin benign histolojide olduğu tümörleri içermekte olup literatürde kompozit adenomkarsinoid, eğer nöroendokrin komponent çok küçük ya da mikroskobik boyutta ise kompozit adenom-mikrokarsinoid olarak isimlendirilmiş̧tir [4]. Ayrıca çalışmalarda, iki neoplastik bileşenin ortak bir prekürsör hücreden kaynaklandığı da bildirilmektedir $[5,6]$. Bu yazıda, bir kompozit kolonik adenom-mikrokarsinoid olgusunda iki neoplastik bileşenin ortak bir kök hücreden kaynak aldığını gösteren ilginç histolojik ve immünhistokimyasal görünümler, literatür bilgileri eşliğinde tartışıımıştır.

\section{Olgu Sunumu}

36 yaşında erkek hasta, dışkıda kanama şikayeti ile genel cerrahi polikliniğine başvurmuştur. Anamnez ve laboratuvar tetkiklerinde özellik izlenmeyen hastanın kolonoskopik incelemesinde; kalın barsak yerleşimli en büyüğü $0,8 \mathrm{~cm}$ olan 15-20 adet polip tespit edilmiş olup en büyük çaplı 4 adet polip eksize edilmiş ve patoloji bölümüne gönderilmiştir.

Poliplerin histopatolojik incelemesinde 4 adet polipte de düşük dereceli displazi gösteren tübüler adenom varlı̆̆ı saptanmıştır. Poliplerlerden $0,4 \mathrm{~cm}$ boyutundaki birinde ise; tübüler adenom içerisinde $0,2 \mathrm{~cm}$ boyutunda, küçük yuva yapıları ve asiner yapılar oluşturan, yuvarlak-oval nükleuslu, ince tanecikli kromatin yapısı gösteren monoton hücrelerden oluşan tümöral infiltrasyon dikkati çekmiştir (Resim 1).

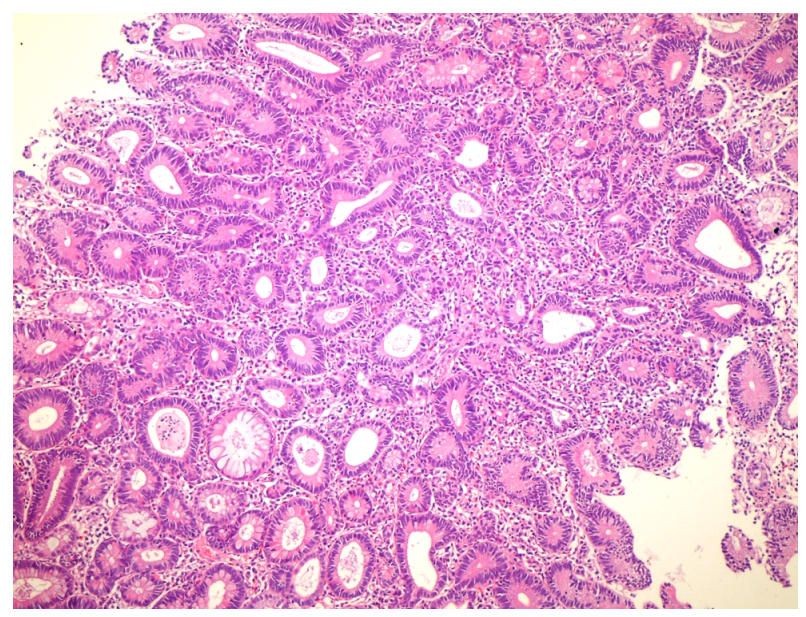

Resim 1. Tübüler adenom içerisinde, küçük asiner yapılar oluşturan tümöral infiltrasyon görülmektedir (40xHE).
Tümörün bazal tabaka altında ve fibröz bir stroma içerisinde yer yer tek hücre şeklinde yerleşim göstermesi yalancı invazyon görünümü vermektedir (Resim 2).

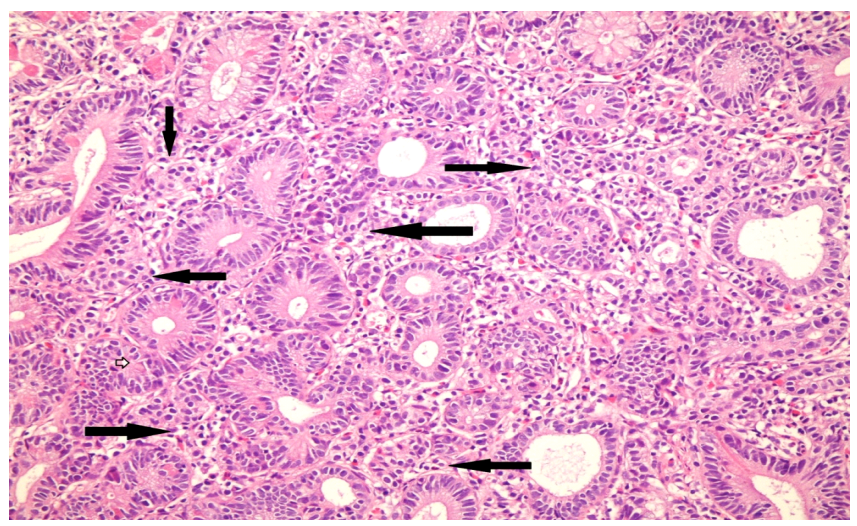

Resim 2. Oklar; küçük yuva-asiner yapılar oluşturan, oval nukleuslu, ince tanecikli kromatin yapısına sahip, monoton hücrelerden oluşan nöroendokrin tümörü göstermektedir (200xHE)

Ayrıca ilginç bir bulgu olarak, nöroendokrin tümörü oluşturan hücrelerin adenomatöz epiteli oluşturan hücrelerle yer yer geçiş göstermekte olduğu dikkati çekmiştir (Resim 3-4).

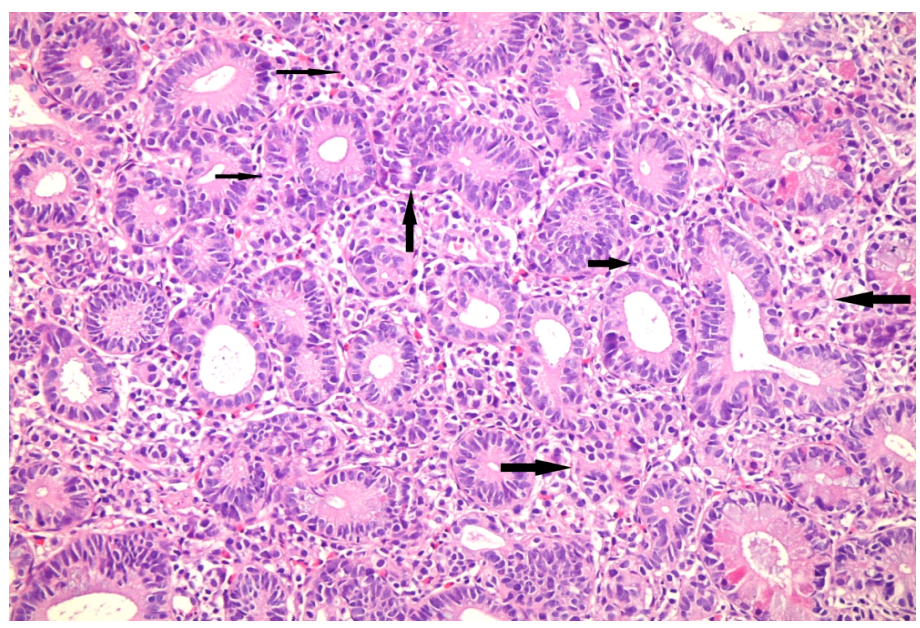

Resim 3. Oklar, nöroendokrin tümörü oluşturan hücrelerin adenomatözepitelleyeryer geçişgösterdiğini belirtmektedir (200xHE).

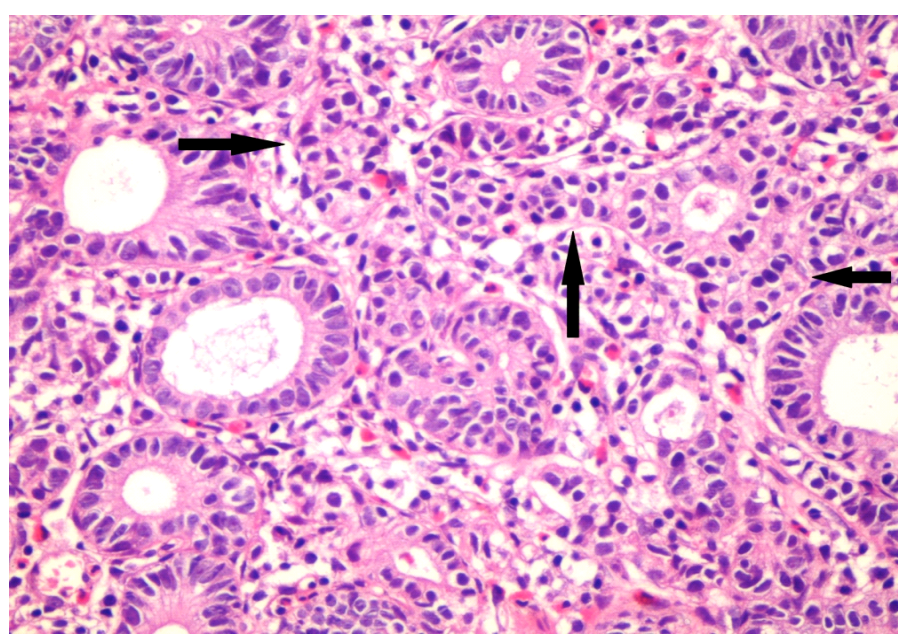

Resim 4. Oklar, nöroendokrin tümörü oluşturan hücrelerin adenomatöz epitelle yer yer geçiş gösterdiğine işaret etmektedir (400xHE). 
İmmünhistokimyasal inceleme: İmmünhistokimyasal çalışmada tümöral hücrelerde sinaptofizin (+) (Resim 5), CD 57 (+), PGP 9,5 $(+)$, kromogranin (-) bulunmuştur

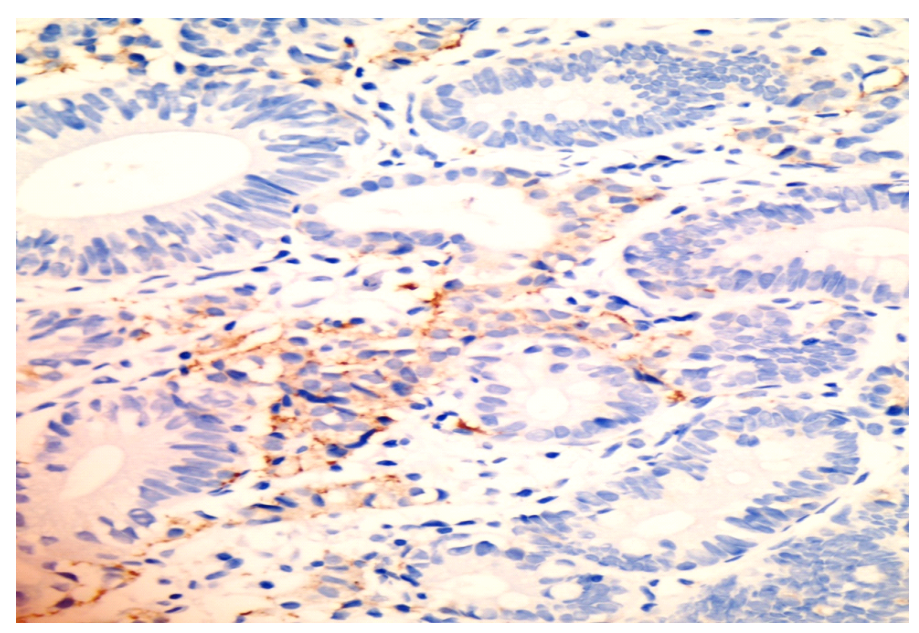

Resim 5. Nöroendokrin komponentde immünhistokimyasal olarak sinaptofizin pozitifliği görülmektedir (400xHE).

Mitoz, nekroz, nükleer atipi, nükleer pleomorfizm görülmemiştir. Adenomatöz epitelde Pansitokeratin ve sitokeratin 20 pozitif boyanmıştır. İlginç bir bir bulgu olarak glandüler komponentde tek hücre şeklinde sinaptofizin pozitifliği olduğu, bazı alanlarda ise sinaptofizin pozitif boyanan nöroendokrin komponentin adenomatöz epitel ile geçiş göstediği tespit edilmiştir (Resim 6). Ki-67 proliferasyon indeksi \%1'den az olarak saptanmıştır.

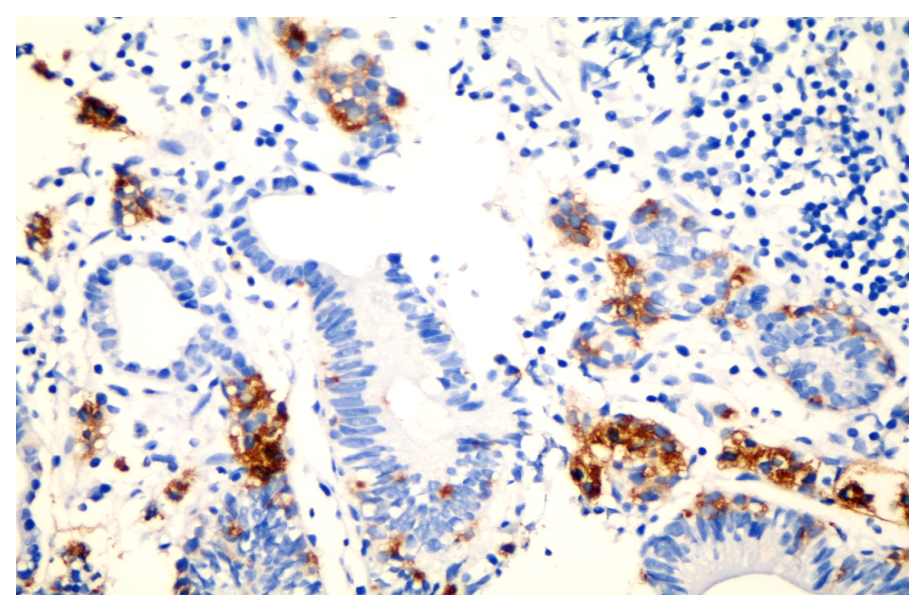

Resim 6. Sinaptofizin pozitif boyanan nöroendokrin komponent ile adenomatöz komponentin geçiş göstermesi ve glandüler komponentde tek hücre şeklinde sinaptofizin pozitiflikleri görülmektedir (400xHE).

Olgu bu bulgular eşliğinde kompozit kolonik adenommikrokarsinoid tümör olarak rapor edilmiştir. Lezyondaki nöroendokrin komponent 'Nöroendokrin tümör, grade 1'olarak değerlendirilmiştir.

\section{Tartışma}

Mikst glandüler-nöroendokrin tümörler; endokrin ve glandüler komponenti birlikte içeren nadir görülen bir tümör grubunu tanımlar [1]. Bu tümörlerde her iki komponent de genellikle malign özellikte olup, her iki komponentin de benign özellikler gösterdiği tübüler adenom ile karsinoid tümör birlikteliği ise son derece nadir [1,2]. Literatürde 'kombine adenommikrokarsinoid' olarak isimlendirilen bu tümörler, tübüler adenom ile birlikte küçük bir nöroendokrin komponent içermektedir [2,3]. Olgumuzda izlenen nöroendokrin komponent çok küçük boyutta olup her iki komponent de benign görünümdedir.

ButümörlerilkkezMoyanatarafından 1988yılındatanımlanmıştır [4]. Kolorektal adenomlarda ve adenokarsinomlarda, immünhistokimyasal olarak nöroendokrin hücre ya da hücre grubu tespiti sık rastlanan bir bulgudur [5]. Ayrıca klasik karsinoid tümörlere glandüler komponentin eşlik ettiği olguların da bildirilmesi ve yapılan moleküler ileri çalışmalar, hem glandüler hem de nöroendokrin komponentin aynı multipotenent kök hücreden kaynak aldığını göstermektedir [6,7]. Olgumuzda da izlenen histolojik ve immunhistokimyasal bulgular, her iki komponentin aynı kök hücreden kaynaklandığını desteklemektedir.

Mikrokarsinoidlerin, midede otoimmun atrofik gastirit ve Zollinger-Ellison sendromu ile ilişkisi literatürde birçok yayında tanımlanmıştır [8,9]. Kalın barsakta ise mikrokarsinoid oldukça nadir olup büyük kısmı kronik inflamatuar barsak hastalıkları özellikle de ülseratif kolit hastalarında, multifokal mikroskobik lezyonlar şeklinde rapor edilmiştir [10]. Kronik kolit ile bu yakın ilişki endokrin hücre hiperplazisi gibi mikrokarsinoidlerin de, barsak mukozasının kronik inflamasyona karşı aşırı proliferatif cevabının sonucunda oluştuğunu göstermektedir $[10,11]$. Olgumuzda ise inflamatuvar barsak hastalığı ile ilişki saptanmamıştır.

İnsidental yakalanması, nöroendokrin hücrelerin etraf stroma ile karışması ve adenomatöz epitelle geçiş göstermesi rutin pratikte bu tümörlerin tanınmasını güç hale getirmektedir $[12,13]$. Ayrıca bazal lokalizasyon, infiltratif patern, glandüler epitele bitişik pleomorfik şekilli hücresel kümeler şeklinde izlenmesi de yanlış olarak yüksek dereceli displazi ya da invaziv adeokarsinom tanılarına götürebilmektedir [14,15]. Olgumuzda da tarif edilen histolojik tanı tuzakları mevcut olup, immünhistokimyasal çalışma ayırıcı tanıda yararlı olmaktadır.

Literatürde kompozit adenom-karsinoid tümör olarak rapor edilen hastaların klinik takipleri genel olarak benign olarak bildirilmiştir [15,16]. Ancak submukoza invazyonu izlenen bir olguda ise lenf nodu metastazı ve agresif davranış tarif edilmiştir [16]. Olgumuzun postoperatif 36 aylık takibinde 
nüks ya da metastaz saptanmamakla beraber, tümörün histolojik görünümünden prognozu tahmin etmek mümkün olmadığından tüm olgular izlenmelidir.

Sonuç olarak olgumuzda izlenen iki neoplastik bileşen arasındaki morfolojik ve immünhistokimyasal yakın benzerlikler, literatürde bildirilen bu tümörlerin ilkel bir öncü hücrenin çok yönlü diferansiyasyonundan kaynaklandığını kavramını güçlendirmiştir. Vaka sayısının arttırılması, bu tümörlerin orijininin anlaşılması ve hedefe yönelik tedaviler için faydalı bilgiler verecektir.

\section{Maddi Destek ve Çıkar İlişkisi}

Çalışmayı maddi olarak destekleyen kişi/kuruluş yoktur ve yazarların çıkara dayalı bir ilişkisi yoktur.

\section{Kaynaklar}

1. Rindi G, Arnold R, Bosman FT, et al. WHO classification of tumours of the digestive system, nomenclature and classification of neuroendocrine neoplasms of the digestive system. International agency for research on cancer, Lyon; 2010: 13-14.

2. Lewin K. Carcinoid tumors and the mixed (composite) glandular-endocrine cell carcinomas. Am J Surg Pathol 1987; 11: 71-86.

3. Lyda MH, Fenoglio CM. Adenoma-carcinoid tumors of the colon. Arch Pathol Lab Med 1998; 122: 262-265.

4. Moyana TN, Qizilbash AH, Murphy F. Composite glandularcarcinoid tumors of the colon and rectum: Report of two case. Am J Surg Pathol 1988; 12: 607-11.

5. Vanden IHF, Vanden BLJ, Verhofstad AA, Bosman FT. Neuroendocrine cells in colorectal adenomas. J Pathol 1986; 148: 231-7.

6. Bansal M, Fenoglio CM, Robboy SJ, King DW. Are metaplasias in colorectal adenomas truly metaplasias? Am J Pathol 1984; 115: 253-65.
7. Vortmeyer AO, Merino MJ, Wang CY, et al. Concordance of genetic alterations in poorly differentiated colorectal neuroendocrine carcinomas and associated adenocarcinomas. J Natl Cancer Inst 1997; 89; 1448-53.

8. Zissis D, Zizi SA, Grammatoglou X, et al. Combined carcinoid and mixed (composite) glandular endocrine cell carcinoma of the stomach in atrophic gastritis. 2009 JanMar; 14 (1): 127-30.

9. Reinecke P, Borchard F. Pattern of gastric endocrine cells in microcarcinoidosis: An immunohistochemical study of 14 gastric biopsies. Virchows Arch 1996; 428: 237-41.

10. Haidar A, Dixon MF. Solitary microcarcinoid in ulcerative colitis. Histopathology 1992; 21: 487-8.

11. Matsumoto T, Jo Y, Mibu R, et al. Multiple microcarcinoids in a patient with long standing ulcerative colitis. J Clin Pathol 2003; 56: 963-5.

12. Salaria SN, Abu Alfa AK, Alsaigh NY, Montgomery E, Arnold CA. Composite intestinal adenoma-microcarcinoid clues to diagnosing an underrecognised mimic of invasive adenocarcinoma. J Clin Pathol 2013; 66: 302-6.

13. Pulitzer M, Xu R, Suriawinata AA, Waye JD, Harpaz N. Microcarcinoids in large intestinal adenomas. Am J Surg Pathol 2006; 30: 1531-6.

14. Li Y, Yau A, Schaeffer D, et al. Colorectal glandularneuroendocrine mixed tumor: Pathologic spectrum and clinical implications. Am J Surg Pathol 2011; 35: 413-25.

15. Thosani N, Rao B, Ertan A, Guha S. Wide spectrum of neuroendocrine differentiation in identical appearing colon polyps: A report of 2 mixed endocrine-glandular polyps. Turk J Gastroenterol 2014 Dec; 25: 242-3.

16. Lin J, Goldblum JR, Bennett AE, Bronner MP, Liu X. Composite intestinal adenoma-microcarcinoid. Am J Surg Pathol 2012; 36: 292-295. 